\title{
Healthy Facts of Organic Food
}

\author{
Bavec $\mathbf{M}^{1}$, Bavec $\mathrm{F}^{1 *}$, Bavec $\mathrm{A}^{2}$ and Robačer $\mathbf{M}^{1}$ \\ ${ }^{1}$ Faculty of Agriculture and Life Sciences, University of Maribor, Slovenia \\ ${ }^{2}$ University Rehabilitation Institute Republic of Slovenia, Slovenia
}

*Corresponding author: Bavec F, Faculty of Agriculture and Life Sciences, University of Maribor, Pivola 10, Hoče/Maribor, Slovenia

\begin{tabular}{|c|c|}
\hline ARTICLE INFO & ABSTRACT \\
\hline Received: 蔧 July 24, 2019 & \multirow{5}{*}{$\begin{array}{l}\text { Generally understood that healthier properties of organic foods are result of specific } \\
\text { agriculture practice without use of synthetic pesticides and fertilizers, antibiotics, } \\
\text { hormones, additives, genetic modified organisms, nanotechnology or changed molecular } \\
\text { structures in food caused by ionizing radiations. The main fact for consumers is that } \\
\text { there is no doubt of negative effects of prohibited materials in organic agriculture on } \\
\text { human health. Several studies showed positive effect of organic agriculture on individual } \\
\text { health promoting compounds in organic food compared to conventional (ie. polyphenols, } \\
\text { polyunsaturated fatty acids, some vitamins, minerals), but studies of organic foods as health } \\
\text { factor are very limited with numerous 'pro et contra' findings and arguments. The fact is } \\
\text { that diverse organic plant origin food from diverse crops in rotation has richer nutritional } \\
\text { value, especially bioactive compounds. Just a few long-term studies with a high number of } \\
\text { respondents show clear benefits, like less allergic symptoms, positive effects on pregnant } \\
\text { and breast women, on child's neuro-behavioural development and on intelligence quotient } \\
\text { due to use of pesticides. }\end{array}$} \\
\hline Published: July 30, 2019 & \\
\hline $\begin{array}{l}\text { itation: Bavec M, Bavec F, Bavec A, } \\
\text { obačer M. Healthy Facts of Organic } \\
\text { ood. Biomed J Sci \& Tech Res 20(1)- } \\
\text { 019. BJSTR. MS.ID.003403. }\end{array}$ & \\
\hline $\begin{array}{l}\text { eywords: Organic Food; Health; Or- } \\
\text { anic Diet; Pesticide Rests; Organic Ag- } \\
\text { culture }\end{array}$ & \\
\hline breviations: OF: Organic Fooc & \\
\hline
\end{tabular}
PCDD: Polychlorinated Dibenzofurans; GMOs: Genetically Modified Organisms

\section{Background}

The general fact is that organic food (OF) production protect nature, takes care for animal welfare and contributes to human health. OF represents approved, certified and clearly labelled food, where is not allowed to use synthetic chemicals like pesticides, quickly soluble fertilizers, hormones, preventive antibiotic treatments, products from nanotechnology and transgenic genetically modified organisms (GMOs) and products produced from or by GMOs. In organic food processing there is also restriction of the use of food additives and ionizing radiation maintaining a true nature of the product. Public preferences and interactive controlled transparency are increasing consumer preferences for organic farming and food. In 2017, 181 countries were involved into organic production, with 69.8 million hectares and market size of 97 billion US dollars. In 2017, 11.7 million hectares or 20 percent more is reported compared with 2016 [1]. One of the most important reasons for increasing demand in consumption of organic foods are health related aspects [2,3]. Numerous factors influence human health, mainly without clear identification. The health outcome of organic vs. conventional food consumption need to be carefully adjusted because of differences in lifestyle patterns (organic consumers are more physically active and less likely smoke) and different diets (in organic diet is usually less meat, and more fruits, vegetables, legumes, beneficial oils and whole grains).

However, long-term studies with large sample of analyzed population in studies to identify potential positive correlations between organic food and health are lacking, because of no financial support for this kind of studies. Two of studies concluded that children on biodynamic diet had a lower prevalence of allergic symptoms [4-6]. Consumption of organic dairy products by the mother during pregnancy and during infancy was associated with $36 \%$ reduction in the risk of eczema at the first two years of child life [7]. But in mentioned studies is not possible to identify separately the effects of organic diet and other lifestyle factors. The fact is that both factors have beneficial effects on less overweight and obesity among adults, reduction in the risk of non-Hodgkin lymphoma [8]. The aim of the paper is to describe shortly an extensive research 
(key word 'organic food' is cited in SCI Direct 408,282 times and in combination with 'health' 179,967 times), their 'pro et contra' findings and give an overview what are healthy facts for increasing organic food consumption.

\section{Nutritional Value and Bioactive Compounds of Organic Foods}

Overall is known and also an extensive review [9] based on 271 sources reported that nutritional differences among conventional and organic crops are limited, if we compare standard crop products like maize, wheat, rice, potato and consumption of fast food meals based on meat, carbohydrates and fats. We cannot change significantly basic nutritional compounds in case of plant or animal species with changing production system. But crop production based on rich crop rotation includes different less underutilized crops from the past can bring richer compounds of diets, with numerous benefits with healthy effects $[10,11]$. Especially are great differences in case of oils. But also in standard foods, like organic vegetables are found out higher contents of bioactive compounds and antioxidant activity [12], phenolic compounds in vegetables and fruits (even 20\% higher), and in meat omega-3 fatty acids [13]. The content of omega- 3 fatty acids can be influenced only with free range system - it is a rule in organic farming.

\section{Different Understanding Long Term Rests of Pollutants and Heavy Metals in Organic Foods}

In this context several studies showed very misleading, unclear or contradictory results. The existing system does not solve mistakes happened in conventional and industrial agriculture practice or problems of industrial soil pollution in some regions. If in the past persistent and toxic pesticides, like hexachlorobenzene, dichlorodiphenyltrichloroethane (DDT), dieldrin, lindane etc. were used, the residues can be found in organic and in conventional foods till the end of their degradation [14]. If the production place is contaminated with environmental pollutants such as polychlorinated biphenyls (PCBs), polychlorinated dibenzofurans (PCDD/FS) or polychlorinated-p-dioxins [15] is clear that existing organic system could not improve mistakes from the past immediately, the live organisms will incorporate the rests in the organic material as long as they are present in the environment.

Similar, uptake of heavy metals depends on pollution of environment in the region, soil $\mathrm{pH}$ and oxidation reduction processes and physiological pathways, use of pesticides and fertilizers - even natural fertilizer (raw phosphates allowed in $\mathrm{OA}$ contain Cd). Generally, in the polluted environmental conditions among production systems and toxicology of foods is practically impossible to interpret differences and environmental evaluation is done before conversion to OA. Research without extensive critical assessment may result in wrong conclusions and understanding. For example, it is clear that there is no heavy metals in organic foods fertilized by natural materials like organic manure or compost, but it can be for example using biochar produced from wastes. Especially for DDT, as a first pesticide with recognized negative effect is known that it has carcinogenic properties. The most important indication for human health show that organic crops have lower content of cadmium than conventional where are used mineral fertilizers, which mostly contain also cadmium ingredients [7].

\section{Actual Pesticides Rests in Organic Foods}

If there is just a $10 \%$ truth about negative facts of pesticides [16] the situation in this case is very problematic. Once again, in organic production and processing is not allowed to use different synthetic compounds, which are the new source of residuals in nature and in foods. The simple understanding is, if there is no use or and there is no contamination from the neighbors, the foods would not content residues. In this case, analyses of urinary pesticide concentrations (like organophosphorus, pyrethroid, 2,4-D and azole) shows that residual concentrations in the urine are in a significantly lover frequency (or no) contamination in organic diet compared to conventional, by children [17] and by adults [18-21]. It is clear that from health science exposure to synthetic pesticides may result in endocrine-disrupting, neurotoxic or carcinogenic properties. Exposure to some pesticides is positively correlated with the risk of non-Hodgkin lymphoma [22-24] and atherosclerosis [25]. Research paper [26] recommended organic food as beneficial for pregnant and breastfeeding women. Extensively studied exposure to different pesticides (authors assume that even Ambiental in distance 2000 m) during pregnancy period is associated with negative effects on neuro-behavioural development [26], like autism [27] and on intelligence quotient $[28,29]$. As consequence of reduced pesticide exposure, consequently organic food helps to avoid negative health effects and reduce external costs of pesticide use [30].

\section{Transgenic Compounds}

In organic food GMO and products produced from or by GMOs are prohibited. But scientifically exist a few 'pro et contra' results and opinions [31]. Additional (for some who contradictory Seralini study) the tumors were caused by GMO feed by rats and associated to glyphosate-based herbicides. According to the report [6] the further studies of effects on endocrine-related effects and gene toxic levels are needed [32]. However, it is taboo regulated by EU Commission base on 'principle of precaution'.

\section{Rests of Hormones, Antibiotics and Additives}

In animal origin organic food production is ban in using hormones and preventive antibiotics treatments compared to prevalent use in conventional animal husbandry which results in resistance to some antibiotics among society [9]. In food processing are also restrictions in using different synthetic additives (ban of chemical and GMO). The resistance on antibiotics is the main problems of industrial animal production, which risk of developing resistance is low in organic farming systems. There is no evident data of health risks for humans due to use of hormones for periodic fertilization of animals in intensive farms, but on the other hand 
exists a lot of negative evidences in case of artificial additives in conventional (non-organic) foods.

\section{Other Facts}

Experimental in vitro studies differ biological activities in organic and conventional foods in various animal cell models and on immune system. This kind of findings gave some indications of different effects on cell, but do not allow strong conclusions and have not been translated into hypothesis of negative influence on humans [8].

\section{Conclusion}

Consuming healthier compounds and avoiding negative effects of artificial compounds and factors in organic food production is a basic healthy fact from general consumer perspective. Another fact for more organic diets is new scientifically confirmed benefits, even due to numerous interdisciplinary and usually long term influences of different compounds and processes associated with organic foods on human heath exist a lack of information. The fact is also that human health is associated out with healthier living style in uncontaminated environment.

\section{References}

1. Willer H, Lernoud J (2019) The world of organic farming. Statistics \& Emerging trends. Fibl \& IFOAM Pp. 351.

2. Hercberg S, Castetbon K, Czernichow S, Malon A, Mejean C, et al. (2010) The Nutrinet-Sante Study: a web-based prospective study on the relationship between nutrition and health and determinants of dietary patterns and nutritional status. BMC public health 10(1): 242.

3. Baudry J, Mejean C, Alles B, Peneau S, Touvier M, et al. (2015) Contribution of organic food to the diet in allergies sample of French adults (the NutriNet-sante Cohort Study). Nutrients 7(10): 8615-8632.

4. Alfven T, Braun Fahrlander C, Brunekreef B, von Mutius E, Riedler J, et al. (2006) Allergic diseases and atopic sensitization in children related to farming and anthroposophic lifestyle - the PARSIFAL study. Allergy 61(4): 414-421.

5. Fagersted S, Hesla HM, Ekhager E, Rosenlund H, Mie A, et al. (2016) Antroposophic lifestyle is associated with a lower incidence of food allergen sensation in early childhood. J Allergy Clin Immunol 137(4): 1253-1256.

6. Manservisi F, Lesseur C, Panzacchi S, Mandrioli D, Falcioni L, et al (2019) The Ramazzini Institute 13-week pilot study glyphosate-based herbicides administered at human-equivalent dose to Sprague Dawley rats: effects on development and endocrine system. Env Health 18 (1): 15 .

7. Kummeling I, Thys C, Huber M, van der Vijer LP, Snijders BE, et al. (2008) Consumption of organic foods and risk of atopic disease during the first 2 years of life in the Netherlands. British J Nutr 99(3): 598-605.

8. EPRS (European Parliamentary Research Service) (2016) Human health implications of organic food and organic agriculture p. 82.

9. Mie A, Andersen HR, Gunnarsson S, Kahl J, Kesse Guyot E, et al. (2017) Human health implications of organic food and organic agriculture: a comprehensive review. Env Health 16: 22.

10. Bavec F, Bavec M (2007) Organic production and use of alternative crops, (Books in soils, plants, and the environment, 116). Taylor \& Francis: CRC Press, Boca Raton; New York, London, pp. 241.

11. Bavec F, Lisec U, Bavec M (2017) Importance of underutilized field crops for increasing functional biodiversity: Chapter 18. In: Şen B, Grillo 0
(Eds.), Selected studies in biodiversity. London, UK: IntechOpen Pp. $377-$ 388.

12. Jakopič J, Slatnar A, Štampar F, Bavec F, Bavec M, et al. (2013) Effect of different production systems on chemical profiles of dwarf French bean (Phaseolus vulgaris L. cv. Top Crop) pods. J Agric Food Chem 61(10): 2392-2399.

13. Srednicka Tober D, Baranski M, Seal C, Roy S, Benbrook C, et al. (2016) Composition differences between organic and conventional meat: a systematic literature review and meta-analysis. British J of Nutrit 115(6): 994-1011.

14. Gomiero T (2018) Food quality assessment in organic vs. Conventional agricultural produce: findings and issues. Appl Soil Ecol 123: 714-728.

15. Gonzales N, Marques M, Nadal M, Domingo JL (2019) Occurrence of environmental pollutants in foodstuffs: A review of organic vs. Conventional food. Food and Chem Tox 125: 370-375.

16. Leu A (2014) The myths of safe pesticides. Acwres USA, pp. 142.

17. Bradman A, Quirós Alcalá L, Castorina R, Aguilar Schall R, Camacho J (2015) Effect of Organic Diet Intervention on Pesticide Exposures in young children living in low-income urban and agricultural communities. Environ Health Perspect 123(10): 1086-1093.

18. Bavec M, Robačer M, Turk K, Bavec A, Bavec F, et al. (2011) Organic and conventional diet influenced organophosphorus pesticide metabolites in urine. In: Pulkrabová, J (Eds.), Book of abstracts. Prague: Institute of Chemical Technology, ICT Prague Press pp. 133.

19. Oates L, Cohen M, Braun L, Schembri A, Taskova R (2014) Reduction in urinary organophosphate pesticide metabolites in adults after a weeklong organic diet. Environ Res 132: 105-111.

20. Curl CL, Beresford SAA, Fenske RA, Fitzpatrick AL, Lu C, et al. (2015) Estimating pesticide exposure from dietary intake and organic food choices: The Multi-Ethnic Study of Atherosclerosis (MESA). Environ Health Perspect 123(5): 475-483.

21. Baudry J, Mejean C, Alles B, Peneau S, Touvier M, et al. (2015) Contribution of organic food to the diet in allergies sample of French adults (the NutriNet-sante Cohort Study). Nutrients 7(10): 8615-8632.

22. Lu C, Toepel K, Irish R, Fenske RA, Barr B, et al. (2006) Organic diets significantly lower children's dietary exposure to organophosphorus pesticides. Environ Health Perspect 114(2): 260-263.

23. Curl CL, Fenske RA, Elgethun K (2002) Organophosphorus pesticide exposure of urban and suburban preschool children with organic and conventional diets. Environ Health Perspect 111(3): 377-382.

24. Schinasi L, Leon ME (2014) Non-Hodgkin lymphoma and occupational exposure to agricultural pesticide chemical groups and active ingredients; a systematic review and meta-analyses. Int J Env Res Public Health 11(4): 4449-4527.

25. Curl CL, Beresford SAA, Fenske RA, Fitzpatrick AL, Lu C, et al. (2015) Estimating pesticide exposure from dietary intake and organic food choices: The Multi-Ethnic Study of Atherosclerosis (MESA). Environ Health Perspect 123(5): 475-483.

26. Grandjean P, Landrigan PJ (2014) Neurobehavioral effects of developmental toxicity. Lancet Neurol 13(8): 330-338.

27. Von Ehrenstein OS, Ling C, Cui X, Cockburn M, Park AS, et al. (2019) Prenatal and infant exposure to ambient pesticides and autism spectrum disorder in children population-based case-control study. BMJ 364: 1962.

28. Gunier RB, Bradman A, Harley KG, Kogut K, Eskenazi B (2017) Prenatal residential proximity to agricultural pesticide use and IQ in 7-year-old children. Environ Health Perspect 125(5): 057002.

29. Coker E, Gunier R, Bradman A, Harley K, Kogut K, et al. (2017) Association between pesticide profiles used on agricultural fields near Maternal residences during pregnancy and IQ at age 7 years. Int J Env Res Public Health 14(5): 506. 
30. Borguet D, Guilemund T (2016) External costs of pesticide use. Sustainable agriculture reviews - Springer P. 35-120.

31. Seralini GE, Mesnage R, Clair E, Gress S, Spirooux de Vendomois J, et al. (2011) Genetically modified crops safety assessments: present limits and possible improvements. Environmental Sciences Europe 23: 10.

ISSN: 2574-1241

DOI: 10.26717/BJSTR.2019.20.003403

Bavec F. Biomed J Sci \& Tech Res

cC) This work is licensed under Creative

Submission Link: https://biomedres.us/submit-manuscript.php
32. De Almeida LK S, Pletschke BI, Frost CL (2018) Moderate levels of glyphosate and its formulations vary in their cytotoxicity and genotoxicity in a whole blood model and in human cell lines with different estrogen receptor status. Biotech 8(10): 438.

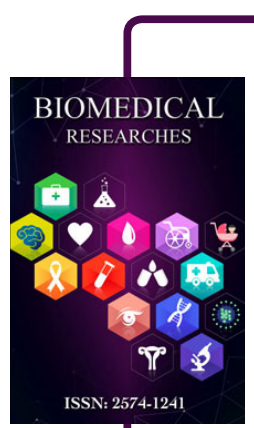

Assets of Publishing with us

- Global archiving of articles

- Immediate, unrestricted online access

- Rigorous Peer Review Process

- Authors Retain Copyrights

- Unique DOI for all articles

https://biomedres.us/ 